\title{
Aristotle and Linguistics
}

P A M Seuren, Max Planck Institute for

Psycholinguistics, Nijmegen, The Netherlands

(c) 2006 Elsevier Ltd. All rights reserved.

The study of language has always had two kinds of practitioners, the practical and the theoretical linguists. Aristotle was no doubt the first theoretical linguist (in addition to being the first in many other subjects), but he also contributed essentially to the development of practical linguistics. His role in the history of linguistics has been highlighted in a few publications (e.g., Seuren, 1998; Allan, 2004).

Aristotle was born in Stagira, in Ancient Macedonia, in 384 в.C.E. His father was the personal physician and a close friend of the king of Macedonia, Amyntas II. An exceptionally gifted boy to begin with, Aristotle joined Plato's Academy in Athens at the age of 17, to remain there until Plato's death in 347. Having been passed over as Plato's successor, he left Athens to live, first, in Asia Minor and then in Lesbos. In 343-342, Amyntas' son and successor, Philip II of Macedonia, invited him to come and teach his son Alexander, then 14 years old. This he did for 2 years. In 336, Alexander succeeded his father and immediately conquered the whole of Greece. Under Alexander's political protection, Aristotle returned to Athens in 335 and founded his school of philosophy, the Lyceum. There he taught until 323, when news of Alexander's death reached Athens. No longer certain of Macedonian protection, he left Athens overnight and sought refuge in Chalcis, just north of Athens, where a Macedonian garrison was stationed. One year later, in 322, he died of an intestinal disease.

His first great contribution to the study of language-not often mentioned-is the fact that he demythologized language. Rather than seeing language as a magical instrument to cast spells, entrance people, and call up past, present, and future spirits, he saw language as an object of rational inquiry, a means of expressing and communicating thoughts about anything in the world. The 'semiotic triangle' of (a) language as the expression of (b) thoughts that are intentionally related with (c) elements in the world, famously depicted in Ogden and Richards (1923: 11), is due to Aristotle. This is Aristotle's most general and perhaps also his most important contribution to the study of language, even if it is not often mentioned by modern authors, for whom it has become a matter of course that language can be seen as a valid object of rational inquiry.

In a more analytical sense, Aristotle's role in the development of linguistics is in large part due to his theory of truth. For him, truth and falsity are properties of either thoughts or sentences. A classic statement is (Metaphysics 1027b25):

For falsity and truth are not properties of actual things in the world (so that, for example, good things could be called true and bad things false), but properties of thought.

A few pages earlier, he defines truth as follows (Metaphysics 1011b26):

We begin by defining truth and falsehood. Falsehood consists in saying of that which is that it is not, or of that which is not that it is. Truth consists in saying of that which is that it is, or of that which is not that it is not.

Here Aristotle introduces not as a simple truthfunctional inverter of truth values: a toggle between true and false. This has momentous consequences.

Aristotle's truth theory is known as the correspondence theory of truth, in that it requires a correspondence between what is the case in the world on the one hand and what is said or thought on the other. To make this notion of correspondence more explicit, some form of analysis is needed. Aristotle made a beginning with that. He analyzes the 'world' as consisting of things that are named by any of the 10 categories substance, quantity, quality, relation, place, time, position, state, action, or affection (Categories 1b25-30). Within the category 'substance,' there is a hierarchy from the primary substances (individual existing entities) through a range of secondary substances, from species and genus to any higher order. The secondary substances together with the remaining 9 categories are properties or things that things are ("everything except primary substances is either predicable of a primary substance or present in it"; Categories 2a33).

On the other hand, he analyzes sentences as resulting from the application of a katêgoroumenon (Latin praedicatum) to something. The something to which the predicate is applied he calls bypokeimenon (literally 'that which underlies'; Latin subiectum or suppositum). Primary substances (entities) can be the object only of predicate application - that is, can only be bypokeimena (Categories 2b39-40). All other things can be either hypokeimena or properties, denoted by a predicate. Yet in orderly talk about the universe, it is proper to take lower categories of substance as the things predicates apply to and reserve predicates themselves for the denoting of higher-order substances and other categories of being (Categories $3 a 1-5)$. 
The combination of a predicate with a term denoting the hypokeimenon Aristotle calls prótasis (Latin propositio). A proposition is true just in case the property assigned to the bypokeimenon actually adheres to it; otherwise it is false. Moreover, a true proposition is made false, and vice versa, by the prefixing of not ("it is not the case that"). The term prótasis occurs for the first time on the first page of Prior Analytics, which contains his doctrine of syllogisms (Prior Analytics 24a16):

A proposition (prótasis) is an affirmative or negative expression that says something of something.

A proposition is divided into terms (Prior Analytics 24b16):

A term (bóron) I call that into which a proposition is analyzed, such as the predicate (katêgoroúmenon) and that to which the predicate is applied.

One notes that Aristotle lacked a word for what we call the subject term of a sentence. During the late Middle Ages, the Latin subiectum began to be used in that sense-an innovation that has persisted until the present time (Seuren, 1998: 121-124).

This was the first semantic analysis of sentence structure in history, presaged by, and probably unthinkable without, Plato's incipient analysis of sentence meaning in his dialogue The Sophist. It is important to note that Aristotle's analysis of the proposition does not correspond to the modern syntactic analysis in terms of subject and predicate, but rather to what is known as topic-comment analysis. The identification of Aristotle's sentence constituent for the denoting of a hypokeimenon with "grammatical subject," characterized by nominative case, and of Aristotle's predicate with "grammatical predicate," may have been suggested by Aristotle, as when he says that a morphological verb "always is a sign of something said of something else" (On Interpretation 16b7). But it was carried through systematically a few decades after Aristotle's death by the linguists of Alexandria, whose task it was to develop teaching material for the Egyptian schools where local children had to learn Greek in the shortest possible time (Seuren, 1998: 21-22). Unfortunately, this identification was, though convenient, rash and ill-considered. It persisted more or less unchallenged until the middle of the 19th century, when some, mostly German, scholars discovered that the Aristotelian subject-predicate distinction does not coincide with the syntactic subject-predicate analysis universally applied in linguistics. For in actual discourse, very often what should be the subject according to Aristotle's definition is not the subject recognized in grammatical analysis, and likewise for the predicate. Steinthal, for example, observed (1860: 101-102):

One should not be misled by the similarity of the terms. Both logic and grammar speak of subject and predicate, but only rarely do the logician and the grammarian speak of the same word as either the subject or the predicate....Consider the sentence Coffee grows in Africa. There can be no doubt where the grammarian will locate subject and predicate. But the logician? I do not think the logician could say anything but that 'Africa' contains the concept that should be connected with 'coffee grows'. Logically one should say, therefore, 'the growth of coffee is in Africa'.

Observations like this gave rise to a long debate, which lasted more than 80 years. At the end, it was decided to keep the terms subject and predicate for the syntactic analysis and speak of topic and comment for the semantic analysis in the Aristotelian sense (see Seuren, 1998: 120-133 for a detailed discussion).

Syntax, in the modern sense, is largely absent from Aristotle's writings. He does, however, distinguish between different sentence types (On Interpretation 17a1-12):

Every sentence is meaningful, not in virtue of some natural force but by convention. But not all sentences are assertions, only those in which there is question of truth or falsity. In some sentences that is not so. Wishes, for example, are sentences but they are not true or false. We will leave all other sentence types out of consideration, as they are more properly studied in rhetoric or poetics. But assertions are the topic of the present study [i.e., logic]. The primary assertive sentence type is the simple affirmation, the secondary is the simple negation. All other, complex, assertions are made one by conjunction. Every assertion must contain a verb or a conjugated form of a verb. For a phrase like "man" is not yet an assertion, as long as no verb in the present, past, or future tense is added.

Some word classes are already there. Thus, at the outset of On Interpretation, he defines ónoma (noun) as "a stretch of sound, meaningful by convention, without any reference to time and not containing any internal element that is meaningful in itself" (On Interpretation 16a19-21). Rhêma (verb) is defined as "that which, in addition to its proper meaning, carries with it the notion of time, without containing any internal element that is meaningful in itself; it always is a sign of something said of something else" (On Interpretation 16b6-8). In his Rhetoric, at 1406a19, Aristotle uses the term epitheton for adjective. All other terms for word classes are of a later date, with many of them having been created by the Alexandrian linguists. 
The term $p t o ̂ s i s$ is found relatively frequently, in the sense of nominal or verbal morphological modification, as in Categories 1a13-15: "Things are said to be named 'derivatively' when they derive their name from some other word that differs in morphological form ( $p t o \hat{s e i}$ ), such as the grammarian from the word grammar or the courageous from the word courage." The literal meaning of ptôsis is 'fall' (Latin: casus). Its use in the sense of morphological modification is based on the metaphor that the word 'as such' stands upright (in the 'upright case' or orthê ptôsis; Latin: casus rectus). Its other falls are represented by forms that are modified morphologically according to some paradigm. The Alexandrians began to reserve the term ptôsis for the nominal cases of nominative (the form of your own name), genitive (the form of your father's name), dative (the name of the person you give something to), accusative (the name of the person you take to court), and vocative (the name of the person you call). These terms smell of the classroom, not of philosophy.

See also: Aristotle and the Stoics on Language.

\section{Bibliography}

Allan K (2004). 'Aristotle's footprints in the linguist's garden.' Language Sciences 26(4), 317-342.

Ogden C K \& Richards I A (1923). The meaning of meaning. A study of the influence of language upon thought and of the science of symbolism. London: Routledge \& Kegan Paul.

Seuren P A M (1998). Western linguistics: An historical introduction. Oxford: Blackwell.

Steinthal H (1860). Charakteristik der hauptsächlichsten Typen des Sprachbaues (Neubearbeitung von Dr. Franz Misteli). Berlin: Dümmler.

\section{Aristotle and the Stoics on Language}

\author{
H Weidemann, University of Münster, Münster, \\ Germany \\ (C) 2006 Elsevier Ltd. All rights reserved.
}

To be "subject to contradiction by scholars" is, as W. V. Quine warns us, "the penalty for attributions to Aristotle" (Quine, 1960: 199). A case in point are the views that have been attributed to Aristotle on the basis of the first chapter of his treatise De interpretatione, the first half of which - i.e., if we leave aside the opening lines of the chapter, the passage from 16 a 3 to 16 a 8 - has rightly been called "the most influential text in the history of semantics" (Kretzmann, 1974: 3). In 1974 two articles appeared, in one of which this text is alleged to be "the only passage of some length in the known works of Aristotle which contains a theory of meaning" (Gyekye, 1974: 71), whereas in the other we are told that "it is not even a sketch of a general theory of meaning" (Kretzmann, 1974: 5). It can be summarized as follows: The expressions of spoken language are symbolized by the expressions of written language and are themselves symbols, or signs, of certain "affections in the soul" (16 a 3-4, cf. 6-7; Ackrill, 1963: 43), which, for their part, are likenesses of things. While these mental affections, of which linguistic expressions are signs in the first instance, as well as the things they are likenesses of are the same for all men, linguistic expressions are not.
According to the traditional interpretation of the text in question (for which see Weidemann, 2002: 134-151; for other texts relevant to Aristotle's theory of language cf. Ax, 1992 and Weidemann, 1996), by saying that mental affections are what linguistic expressions are "in the first place signs of" (16 a 6; Ackrill, 1963: 43), Aristotle implies that linguistic expressions are in the second place signs of the things of which the mental affections they primarily signify are likenesses. Interpreted in this way, our text does indeed sketch out a semantic theory.

At first sight this theory might remind a modern reader of the sort of 'uncritical semantics' described by Quine as "the myth of a museum in which the exhibits are meanings and the words are labels" (Quine, 1969: 27). That Aristotle is not committed to this "mentalistic myth of the meaning museum" (Quine, 1969: 30), however, is shown by the way in which he explains what it is for spoken words to signify something. A spoken word, he points out in De interpretatione 3 (16 b 20-21), signifies something by virtue of the fact that "the speaker arrests his thought and the hearer pauses" (Ackrill, 1963: 45). As the passage in Plato's Cratylus to which Aristotle is alluding here (437 a 4-5) makes clear, it is the thing referred to by a word at which, according to Aristotle, "the speaker arrests his thought" and upon which "the hearer pauses." This answers the question in what sense the mental affections mentioned in the first half of De interpretatione 1, which in the second 